\title{
Managerial decision-making on the location of banking headquarters in the Czech Republic
}

\author{
Jan Sucháček ${ }^{1 *}$ - Jolana Skaličková2 - Jan Široký ${ }^{1}$ \\ ${ }^{1}$ VŠB-Technical University of Ostrava, Faculty of Economics, Czech Republic \\ * Corresponding author. Email: jan.suchacek@vsb.cz \\ ${ }^{2}$ Moravian University College Olomouc, Czech Republic
}

\begin{abstract}
Location decision-making constitutes one of pivotal tasks for banking managements, which applies to both banking headquarters and affiliates. The main objective of this article consists in analysis and interpretation of location factors that stay behind location-decision making of banking managements and subsequent collocation of banking head offices in the Czech Republic. In doing so, cluster analysis was utilised appropriately and it turned out, initial 18 location factors can be decreased to final three mutually similar groups, which satisfactorily embody location criteria banking managements take into account. As it has been proven banking landscape in the Czech Republic is still influenced by traditional hard factors of location, nonetheless their soft counterparts should be increasingly considered.
\end{abstract}

Key words: Banking managements, banking sector, location decisions, banking headquarters, Czech Republic.

Highlights for public administration, management and planning:

- Physical location of banking headquarters is still of primary importance and location factors should be monitored carefully.

- Rising importance of soft location factors in the post-transformation countries may be expected.

Received: 20 Aug 2017 - Received in revised form: 9 Oct 2017 - Accepted: 20 Oct 2017

\section{Introduction}

Every economy can be characterised by a specific spatial configuration. Large cities represent important nodes in the framework of these economies. Contemporary sharp interurban competition brought a new pressure on particular urban managements (Ježek 2011).

They strive to attract various target groups including new investors, tourists or students as well as many others. Banks represent one of the most relevant target groups in this context and it concerns both banking headquarters as well as branches. It can be stated that geographical distribution of banking headquarters embodies spatially strongly differentiated economic power. This is the natural reflection of the fact that banks constitute one of the most relevant entities within the economy and seats of their manage- ments where pivotal decisions take place, should be monitored thoroughly (see also Bassens \& van Meeteren 2015; Cohen, 1998; Karreman 2009; Porteous 1995; Pike \& Pollard 2010 or Alessandrini et al. 2005).

The main objective of this paper is to analyse and interpret location factors that affect locationdecision making of banking managements and subsequent collocation of banking head offices in the Czech Republic.

In this article, we strive for the application of less frequent approach towards the analysis of banking institutions, which is however indispen-sable for the indication of geographical differen-tiation of financial-economic power on the one hand and for the qualified and datadriven location decision-making of banking manage-ments on the other. 


\section{Spatial-Managerial View on Banking Sector and Banking Institutions}

Banks can be generally perceived as the hubs of the geography of finance. Taking deposits and granting credits that embody principal functions of the banks bear a distinct spatial dimension even within single countries. Put succinctly, flows of finance are based on particular decisions of banking managements, which are located in individual cities. Undoubtedly, managers placed in banking headquarters play a cardinal role in that context (see also Vanhove \& Klaasen 1987; Corbridge et al. 1994; Martin \& Minns 1995; Karreman 2009; Alessandrini et al. 2005; Bassens \& van Meeteren 2015; Pike \& Pollard 2010 or Sokol 2011).

This implies that geography of finance is of crucial importance and space and place matter for financial transactions and allocations (see also Corbridge et al. 1994; Martin \& Minns 1995; Karreman 2009; Cohen 1998; Pike \& Pollard 2010; Dow 1999; Leyshon \& Thrift 1997; Lee et al. 1997; Sass \& Fifeková 2011; Taylor \& Csomos 2012 or Bassens \& van Meeteren 2015).

Semple (1985) introduced quaternary place concept concentrating on strong interconnectedness of banks with other producer services. Porteous (1995) underlines the importance of face-to-face contacts, concomitant to actors living in large metropolitan areas. This, in turn, leads to the depression of transactions costs.

Contrary to that, actors living in more remote territories are often disadvantaged geographically, socio-culturally as well as in terms of transaction costs as shown by Sucháček (2012). Gál (2004) claims peripheral regions are endangered by financial exclusion.

Strong spatial concentration of banks has been confirmed by numerous authors including Semple (1985), Porteous (1995) or Gál (2004). As confirmed by Krugman (1991), cumulative mech-anisms supporting geographical concentration of banking head offices are distinctively prevailing. Not surprisingly, banking sector is concentrated more than other branches of the economy (Gál 2004).

Nonetheless, one should take into consideration that the above mentioned conceptions explaining the location of banks are applicable mostly in advanced leading economies. The situation in banking sector in Central East Europe (where the Czech Republic can be ranked) is strongly affected by recent intense transformations of these economies (see Hlaváček 2013; Lux 2008; Sucháček et al. 2017 or Sucháček et al. 2016).

Thus, in the Czech Republic as well as other Central East European economies that get through post-transition stage of its development the applicability of conceptions concentrating on the spatial patterns of banking institutions will be partly constrained. This naturally affects also location decision-making on banking headquarters adopted by respective banking managements.

\section{Applied Methods}

The whole research has been executed through questionnaire survey including 20 questions in total. The research was largely of qualitative character. Basic sample was composed of 24 commercial banks with head offices in the Czech Republic. Data gathering was accomplished by means of electronic and telephone questioning. Respondents were represented by the members of top or middle managements in individual banks.

At the beginning, all banks were addressed by means of e-mail. In case of no response, respective managers were contacted via telephone when the purpose of the whole research was explained to them. In case of their approval they finally received the questionnaire via e-mail. At the end, 21 banks joined the research and the rate of return thus reached satisfactory value 87.5\%.

For the purposes of our research, structured questionnaire turned out appropriate. We utilized Likert scale ranging from -3 to +3 . The higher value, the higher intensity of the examined phenomenon. While -3 marks utter disagree-ment, +3 denotes complete agreement and 0 is a neutral medium value. This scale was applied in the major part of questions. Further interesting and specific information that facilitated the completion of the whole research were obtained by means of open questions within our questionnaire. Our attention concentrated mainly on the issues with high 
frequency of occurrence, but we regarded also other information gained within this research.

Data were further processed and analysed by Microsoft Excel and SPSS 21, software for mathematical and statistical calculations.

Generally speaking, cluster analysis, which is utilised also in this article, is based on the division of objects. The purpose of cluster analysis consists in the maximisation of the resemblance of objects in the framework of individual clusters and concurrently maximisation of mutual dissimilarity among individual clusters. Cluster analysis leads to the decrease of the number of objects. Final amount of objects is smaller than original amount of objects (see also Řezanková 2006 or Hendl 2012). In our article we strived for the application of hierarchical cluster analysis. The result is the construction of a hierarchy, or dendrogram (treelike structure), depicting the formation of the cluster (see also Hair at al. 2010).

Distances in the framework of hierarchical cluster analysis can be quantified in different ways. In this paper, Euclidean measure was applied, which is expressible in the following way:

$$
\operatorname{distance}(x, y)=\sum_{i=1}^{n}\left(x_{i}-y_{i}\right)^{2},
$$

where $x(x 1, x 2, \ldots, x n)$ and $y(y 1, y 2, \ldots, y n)$ are multivariate objects.

In this article, Ward's linkage method was applied. Ward's linkage method minimizes the sum of squares of any two theoretical clusters, which can be generated at every step of clustering (Ward 1963). Generally speaking, Ward's method is treated as rather efficient and taking into account the size of data sample, we are entitled to utilize it. In that way, we will get the optimal number of clusters, which will be further interpreted.

Last but not least, we should be aware of natural spatio-temporal constraints of this research and that is why its results should be treated with high degree of caution. The problem of the location of banking headquarters is very lively and its variability and versatility do not enable us to draw any larger general conclusions. Interestin- gly, rather small amount of research has been done on that topic so far, which creates sufficient space for added value of the paper as well as future researches.

\section{Results}

Location decision-making related to the head offices of respective banks is one of fundamental tasks for banking managements. Location factors that matter are synthetically depicted in Table 1.

Table 1 - Statistical Description of Location Factors for Banking Headquarters

\begin{tabular}{lcrr} 
Location factor & Mean & Mode & \% Mode \\
\hline Geographic location & 1.86 & 3 & 43 \\
$\begin{array}{l}\text { Infrastructure } \\
\begin{array}{l}\text { Quality of } \\
\text { entrepreneurial milieu }\end{array}\end{array}$ & 1.76 & 3 & 38 \\
$\begin{array}{l}\text { Quality of local } \\
\text { workforce }\end{array}$ & 1.14 & 2 & 24 \\
$\begin{array}{l}\text { Proximity of decisive } \\
\text { authorities }\end{array}$ & 0.86 & 0 & 33 \\
$\begin{array}{l}\text { Availability/quantity of } \\
\text { workforce }\end{array}$ & 0.76 & 3 & 38 \\
$\begin{array}{l}\text { Image/prestige of the } \\
\text { place }\end{array}$ & 0.71 & 2 & 38 \\
$\begin{array}{l}\text { Closeness of similar } \\
\text { firms/financial services }\end{array}$ & 0.52 & 0 & 43 \\
$\begin{array}{l}\text { Public administration } \\
\text { system }\end{array}$ & 0.43 & 0 & 48 \\
$\begin{array}{l}\text { Land price } \\
\text { Proximity to }\end{array}$ & 0.14 & 1 & 33 \\
$\begin{array}{l}\text { competitors } \\
\text { National policies }\end{array}$ & 0.10 & 0 & 33 \\
$\begin{array}{l}\text { Agglomeration } \\
\text { advantages }\end{array}$ & 0.05 & 0 & 43 \\
$\begin{array}{l}\text { Willingness of } \\
\text { managers to move }\end{array}$ & -0.29 & 0 & 38 \\
$\begin{array}{l}\text { Low wage } \\
\text { requirements }\end{array}$ & -0.81 & 0 & 33 \\
$\begin{array}{l}\text { Quality of } \\
\text { environment } \\
\text { Cultural facilities }\end{array}$ & -1.29 & -3 & 43 \\
$\begin{array}{l}\text { Sport facilities } \\
\text { for }\end{array}$ & -1.38 & -3 & 38
\end{tabular}

As it can be derived from Table 1, the most important location factors influencing the collocation of banking headquarters are 
geographical location and infrastructure. On the above mentioned Likert scale, the value ' 3 ' means the highest intensity of the phenomenon concerned and as it can be seen, $43 \%$ of questioned managers assessed the location factor 'geographical position' just by that value and $38 \%$ of respondents evaluated the next location factor called 'infrastructure' in the same manner.

Large values can be found also in case of mean evaluation of the quality of entrepreneurial environment and quality of local labour. The most frequented value was ' 2 ' in both cases, which also signifies rather large relevance of both location factors for banking managements in the Czech Republic.

Contrary to that, sport and cultural amenities, quality of environment, low wage requirements, willingness of managers to move and agglomeration advantages can be found at the bottom of the hierarchy of location factors determining the collocation of banking headquarters in the country. In case of cultural and sport facilities, the most frequented value in the frame of Likert scale was ' -3 '.

Table 2 - Clustering Schedule

\begin{tabular}{ccccccc} 
Stage & \multicolumn{2}{c}{$\begin{array}{c}\text { Clusters Combined } \\
\text { Cluster } \mathbf{1}\end{array}$} & Cluster $\mathbf{2}$ & Coefficients & $\begin{array}{c}\text { Stage, at which Cluster First } \\
\text { Appears }\end{array}$ & Next Stage \\
& Cluster 1 & Cluster 2 & \\
\hline 1 & 1 & 2 & 0.005 & 0 & 0 & 12 \\
2 & 3 & 12 & 0.063 & 0 & 0 & 7 \\
3 & 10 & 15 & 0.178 & 0 & 0 & 10 \\
4 & 7 & 8 & 0.329 & 0 & 0 & 16 \\
5 & 11 & 16 & 0.487 & 0 & 0 & 8 \\
6 & 5 & 14 & 0.670 & 0 & 0 & 11 \\
7 & 3 & 9 & 0.896 & 2 & 0 & 12 \\
8 & 11 & 17 & 1.271 & 5 & 0 & 9 \\
9 & 11 & 18 & 2.025 & 8 & 0 & 13 \\
10 & 10 & 13 & 2.888 & 3 & 0 & 13 \\
11 & 5 & 6 & 3.825 & 6 & 0 & 14 \\
12 & 1 & 3 & 5.780 & 1 & 7 & 15 \\
13 & 10 & 11 & 7.996 & 10 & 9 & 14 \\
14 & 5 & 10 & 10.980 & 11 & 13 & 16 \\
15 & 1 & 4 & 14.949 & 12 & 0 & 17 \\
16 & 5 & 7 & 33.625 & 14 & 4 & 17 \\
17 & 1 & 5 & 78.658 & 15 & 16 & 0
\end{tabular}

This is in consonance with previous studies evaluating the location preferences of largest enterprises (see for instance Sucháček 2015). In a real life, these soft location factors, such as sport or cultural amenities, are actually perceived rather intensely. Managers, who answered the questions in the framework of our questionnaire, considered their loyalty to the employers and tended to accentuate rather hard factors directly influencing the economy of banks. In that way, questioned managers indirectly declared their fidelity to their banks.
As mentioned, in order to reduce the number of location factors, cluster analysis has been used. Factor analysis could not be applied just for the sake of the low value of Kaiser-Meyer-Olkin measure of sampling adequacy that reached 0.402. Table 2 provides us with some important information on the cluster analysis performed by the authors and shows how the factors are joined at each stage of the cluster analysis. Fig. 1 represents a dendrogram showing similarities between localization factors.

This agglomeration table presents the results of individual rounds of hierarchical cluster analysis. 
The first column of the table shows the amount of stages or rounds of clustering, when in the last stage the analysed objects are connected into one cluster. The column denoted as 'clusters combined' shows the number of clusters or the numbers of objects that were combined in individual steps.

Coefficients represent the values of significant distances for the combination of clusters.

\footnotetext{
Geographic location

Infrastructure

Quality of local workforce

Quality of entrepreneurial milieu

Image/prestige of the place

Availability/quantity of workforce

Sport facilities

Cultural facilities

$>$

Low wage requirements

Willingness of managers to move

Quality of environment

Closeness of similar firms/financial services

National policies

Agglomerations advantages

Land price

Proximity of decisive authorities

Public administration system

Proximity to competitors
}

\section{Dendrogram using Ward Linkage}

Rescaled Distance Cluster Combine

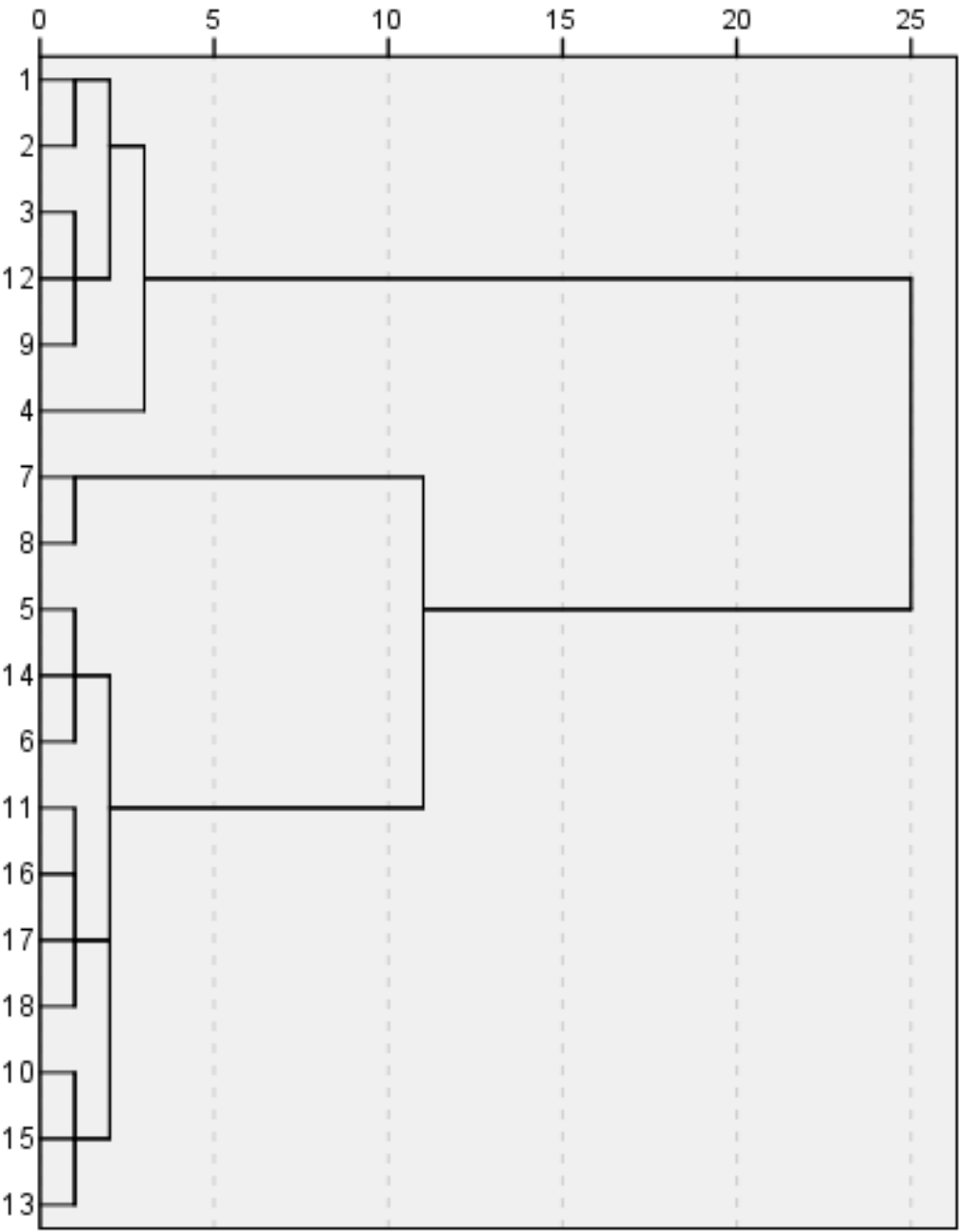

Fig. 1 - Dendrogram for banking headquarters

On the basis of the development of these coefficients we determine the optimal amount of clusters. The process of connection progresses until the moment in time, when all the factors are joined in one large cluster, which is represented by the line 17 . The sudden change of coefficients, which is between lines 15 and 16, represents the solution in the form of three formed clusters. Initial group of 18 location factors was on the basis of cluster analysis dissolved into three clusters. And as it turned out, these clusters can be labelled satisfactorily: 
(a) Geographical location, infrastructure, quality of local workforce, quality of entrepreneurial environment, image/prestige of the place, availability/quantity of workforce - wider geographical factors and human resources.

(b) Low wage requirements, willingness of managers to move, quality of environment, closeness of similar firms/financial services, national policies, agglomeration advantages, land price, proximity of decisive authorities, public administration system and proximity to competitors - place-specific characteristics and political framework.

(c) Cultural facilities and sport facilities - leisure amenities.

It is worth noticing that while cluster a) includes 6 items or location factors and b) comprises 10 original location factors, cluster $\mathrm{c}$ ) is composed of mere two items. It should be stated, however, that clustering finds its rationale in our case and 3 clusters express the characteristics of location factors in a satisfactory manner. Naturally, this is useful also from the perspective of locationdecision making banking managements are in charge.

\section{Discussion and Conclusions}

Banking managements perform different functions and tasks, of which location decisionmaking remains one of the most important ones. Our research disclosed that traditional hard location factors are still of primary importance in the process of collocation of banking head offices in the Czech Republic. It concerns mainly geographic location and infrastructure that seem to be considered most intensely by respective banking managements.

On the contrary, some location factors were revealed as less important. This holds true for sport and cultural amenities, quality of environment, low wage requirements, willingness of managers to move and agglomeration advantages. Average assessment of these location factors in the framework of our questionnaire reached negative values.
The position of cultural and sport facilities looks surprising. This phenomenon can be accounted for by less sincere attitude of the respondents of our questionnaire survey. In reality, these managers do take care of sport and cultural amenities but since these categories do not directly influence economic results of banks, they received only marginal attention. In that way, questioned managers indirectly declared their fidelity to the bank in question.

Cluster analysis turned out to be enormously useful for the purposes of our research and paper. We were able to create 3 clusters that rather satisfactorily characterise relevant attributes of individual factors of location. These clusters were named as follows: wider geographical factors and human resources, placespecific characteristics and political framework and leisure amenities.

If we compare the outcomes of our research with similar studies accomplished abroad, it is apparent that transformation processes in the country influenced also the spatial distribution of banking headquarters. Changes in the location of these headquarters represent one of spatial manifestations of intense transformation of financial and banking sector that took place in the framework of the abandonment of central planning and move to the market-based resource allocation. Similar trends - either more centripetal, such as in Hungary or more polycentric, which was the case of Poland, could be contemplated also in other Central East European countries (Stryjakiewicz \& Potrzebowski 1996; or Gál 2004).

It should be stated specific institutional heritage and strong socioeconomic path-dependency in the Czech Republic that distinctively affected geographical distribution of banking headquarters in the country, are accompanied by rather homogenous settlement system. This settlement structure, which due to its long-term evolution and quite a great inertia embodies the natural developmental premises of individual territories, represents a specific supply side for the location of banking head offices. However, the geographical pattern of banking seats in the country is much more concentrated. 
As confirmed by previous researches (Sucháček 2016), the capital city occupies exclusive position in terms of banking headquarters in the country. The main advantages of the city were identified by our respondents as follows: proximity of clients, nearness of central institutions and the prestige of the capital city. Other towns conceivable as the seats of banking head offices were Brno (seven times), Ostrava (four times) and Plzen (once). The main motives for the possible collocation of banking head offices to these towns were relatively cheap and qualified labour. No other towns in the Czech Republic that could possibly act as hosts of banking headquarters, were mentioned.

This is not in consonance with spatial distribution of banking head offices in advanced economies, which evolved over long periods of time and generally tend to follow settlement systems of respective countries as well as agglomeration economies. Naturally, size of individual economies should be taken into consideration too (see also Bassens \& van Meeteren 2015; Cohen 1998; Corbridge et al. 1994; Karreman 1999; Sokol 2011 or Dow 1999).

There are several recommendations that can be derived from our findings and apply to both public administration and banking managements:

- In spite of rising electronisation and internetisation of banking, physical location is still of primary importance. It includes both tangible, e.g. economic and intangible, e.g. image or prestige components. Thus, it represents an inseparable part of banking management and related location factors should be monitored carefully.

- Advanced countries enjoy sui generis ubiquitous hard location factors and concentrate nowadays rather on their soft counterparts. Post-transformation economies still find themselves qualitatively one step behind and focus on hard location factors rather than their soft peers so far. This implies rising importance of soft location factors in the future as the territories posttransformation countries occupy are getting increasingly standardised in terms of physical infrastructure.
- As mentioned, banking managements can imagine their headquarters only in three other towns out of the capital city. This implies that these towns as well as other large towns should concentrate on the cultivation of both hard and soft factors of location in order to draw on the needs of sustainable socioeconomic development.

\section{References}

Alessandrini P, Croci M, Zazzaro A (2005) The Geography of Banking Power: Role of Functional Distance. PSL Quarterly Review 58, 235: 129-167.

Bassens D, van Meeteren M (2015) World Cities under Conditions of Financialized Globalization. Towards an Augmented World City Hypothesis. Progress in Human Geography 39(6): 752-775.

Cohen BJ (1998) The Geography of Money, Ithaca and Cornell University Press, London.

Corbridge S, Martin R, Thrift N Eds. (1994) Money, Power and Space. Blackwell, Oxford.

Dow S (1999) The Stages of Banking Development and the Spatial Evolution of Financial Systems. In: Martin R (Ed) Money and the Space Economy. John Willey and Sons Chichester, pp. 31-48.

Gál Z (2004) Spatial Development and the Expanding European Integration of the Hungarian Banking System, Pécs, Centre for Regional Studies Discussion Papers.

Hair J, Black W, Babin B, Anderson R (2010) Multivariate data analysis. Prentice Hall, New Jersey.

Hendl J (2012) Kvalitativní výzkum. Portál, Praha.

Hlaváček P (2013) Economic and Innovation Adaptability of Regions in the Czech Republic. In: Proceedings of the 11th International Conference Liberec Economic Forum, pp. 194-203.

Ježek J (2011) Městský marketing - koncepty, aplikace, kritická analýza. Ekonomický časopis 59(3): 243-258.

Karreman B (2009) Financial Geographies and Emerging Markets in Europe. Tijdschrift voor Economische en Sociale Geographie 100(2): 260-266.

Krugman P (1991) Geography and Trade. MIT, Cambridge, Massachusets.

Lee R, Wills J et al. (1997) Geographies of Economies, , Arnold, London.

Leyshon A, Thrift N (1997) Money/Space: Geographies of Monetary Transformation. Routledge, London.

Lux G (2008) Industrial Development, Public Policy and Spatial Differentiation in Central Europe: Continuities 
and Change. Centre for Regional Studies Discussion Papers, , Pécs.

Martin R, Minns R (1995) Undermining the Financial Basis of Regions: The Spatial Structure and Implications of the UK Pension Fund System. Regional Studies 29(2): 125-144.

Pike A, Pollard J (2010) Economic Geographies of Financialization. Economic Geography 86(1): 29-51.

Porteous DJ (1995) The Geography of Finance. Aldershot, Avebury.

Řezánková H (2006) Shluková analýza dat. Professional Publishing, Praha.

Sass M, Fifeková M (2011) Offshoring and Outsourcing Business Services to Central and Eastern Europe: Some Empirical and Conceptual Considerations. European Planning Studies 19(9): 1593-1609.

Semple K (1985) Toward a Quarternary Place Theory. Urban Geography 6(4): 285-296.

Sokol M (2011) Economic geographies of Globalisation. A Short Introduction. Edward Elgar, Cheltenham.

Stryjakiewicz T, Potrzebowski G (1995) The newly emerging banking system in Poland and its spatial organization. Geographische Zeitschrift 83(2): 87-99.

Sucháček J (2012) The Changing Geography of Czech Banking. European Journal of Social Sciences 28(1): 79-91.
Sucháček J (2015) Large Enterprise Branches: the Case of the Czech Republic. Economics and Sociology 8(4): 82-93.

Sucháček J (2016) Diferenciace lokalizačních faktorů bankovních poboček v České republice. In: Klímová V, Žitek V (Eds) 19th International Colloquium on Regional Sciences, pp. 191-195.

Sucháček J, Sed’a P, Friedrich V, Wachowiak-Smoliková, R, Wachowiak MP (2016) From Regional to National Clouds: TV Coverage in the Czech Republic. PLoS ONE 11(11) e0165527.

Sucháček J, Sed'a P, Friedrich V, Koutský J (2017) Regional Aspects of the Development of Largest Enterprises in the Czech Republic. Technological and Economic Development of Economy 23(4): 649-666.

Taylor PJ, Csomos G (2012) Cities as Control and Command Centres: Analysis and Interpretation. Cities 29(6): 408-411.

Vanhove R, Klaasen LH (1987) Regional Policy: A European Approach. Aldershot, , Avebury.

Ward JH (1963) Hierarchical Grouping to Optimize an Objective Function. Journal of the American Statistical Association 58: 236-244. 